\title{
PENGARUH AGAMA DAN BUDAYA TERHADAP ETOS KERJA PEBISNIS MUSLIM SUKU BUGIS DI KABUPATEN NUNUKAN KALIMANTAN UTARA
}

\author{
Rahmani Timorita Yulianty dan Mega Octaviani \\ Prodi Ekonomi Islam FIAI UII \\ email: rahmani_ty@yahoo.com
}

\section{ABSTRACT}

Business regarded as a battlefield. Plunging into the business means being ready to fight it out with the ultimate goal to reach benefit, even profit maximization. It does not mean giving tolerance to business activities deviated from ethics. Precisely ethics has a very strategic place in business. This research about Bugis moslem in Nunukan (its mean they are immigrant), that they achieved succesful in doing business as businessmen and traders. The results showed that religious and cultural background influence on the work ethic of Moslem Bugis in Nunukan North Borneo when they doing business. Their practical business related to the business activities practiced by the Prophet Muhammad, namely: honesty, discipline, and paying zakat and charity. Hard work is their effort to keep their self-esteem as identity of Bugis tribe.

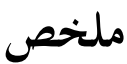

تعتبر الأعمال التجارية كساحة المعركة. تغرق في العمل التجاريبمعنى أن يكون فاعله على استعداد للمحاربة مع الهدف النهائي الوصول إلى المنافع، حتى تعظيم الربح. وهذا لا يعني إعطاء التسامح لأنشطة الأعمال التجاريةلانحرافه عن الأخلاق. على وجه التحديد، الأخلاق لما مكان استراتيجي جدا في بحال الأعمال التجارية. هذا البحث عن المسلمين ببوغيسفي نونوكان (هم من المهاجرين)، أهم حققوا النجاح في التعامل كرجال الأعمال والتجار. وأظهرت النتائج أن تأثير الخلفية الدينية والثقافية على أخحاق العمل من المسلمين ببوغيس في نونوكان بورنيو الشمالية عند ممارسة 


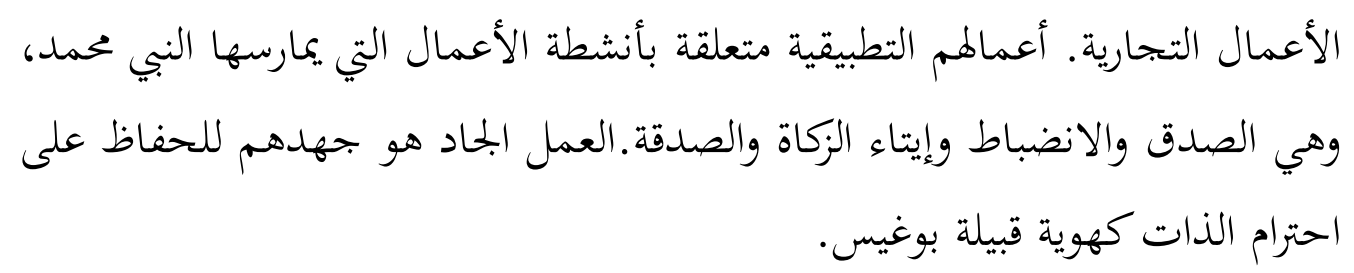

Key words: Agama, Budaya, Etos Kerja, Pebisnis Muslim, Kabupaten Nunukan

\section{A. Pendahuluan}

Islam memiliki pedoman dalam mengarahkan umatnya untuk melaksanakan amalan. Pedoman tersebut adalah al-Qur'an dan Sunnah Nabi. Sebagai sumber ajaran setidaknya dapat menawarkan nilai-nilai dasar atau prinsip-prinsip umum yang penerapannya dalam bisnis disesuaikan dengan perkembangan zaman dan mempertimbangkan dimensi ruang dan waktu. Islam seringkali dijadikan sebagai model tatanan kehidupan yang berbudaya. Praktik bisnis Islam telah banyak dipraktikkan oleh Nabi Muhammad SAW.

Dari sejarah Nabi Muhammad sebagai pedagang yang sukses, ini menjadi praktik secara universal pada semua kalangan umat beragama, tidak hanya Islam. Seperti dalam penelitian Weber tentang etika protestan yang berpengaruh dengan semangat kapitalisme dalam bukunya yang berjudul "The Protestant Ethic and The Spirit of Capitalism" pada tahun 1905. Weber mengatakan, bahwa ada kaitan antara agama dengan tingkah laku kewirausahaan yang menyebabkan terjadinya perkembangan suatu masyarakat tersebut terhadap makna kerja. Dalam tesis Weber menggunakan metode Protestant Calvinist, bahwa terdapat suatu kebudayaan yang menganggap bahwa kerja keras adalah suatu keharusan bagi setiap manusia untuk mencapai kesejahteraan spiritual. ${ }^{1}$

Berkenaan dengan kenyataan ini ahli-ahli ekonomi dan sejarah sosial merupakan kelompok pertama yang menafsirkan etika protestan sebagai suatu hipotesis yang kuat. Kepercayaan kaum Calvinist dianggap telah melahirkan “kapitalis modern". ${ }^{2}$ Bangkitnya kapitalisme sebagai hasil dari kebangkitan

1 Mubyarto dkk. Etos Kerja dan Kohesi Sosial Masyarakat Sumba, Rote, Sabu, dan Timor Provinsi Nusa Tenggara Timur, (Yogyakarta: Cet. II. P3K-UGM, 1992), hal. 2.

2 Amintore Fantani,. Catholicism, Protestant and Capitalism. (London: Sheed and Ward Ltd., 1935), hal. 200-201. 
semangat kapitalisme. Pengikut Calvinist sedikit bersifat aktif, radikal dan revolusioner. Yang mereka lakukan tidak semata diarahkan untuk menata kemurnian kehidupan seseorang, tetapi juga untuk merekonstruksi kembali struktur kehidupan masyarakat secara keseluruhan. Dalam pandangan mereka hidup manusia harus selalu disinari oleh ruh agama. Dengan kata lain acuan bergereja, bernegara dan bermasyarakat haruslah benar-benar mencerminkan suasana kitabiah yang bersumber pada kaidah keagamaan. ${ }^{3}$ Ini tidaklah mengherankan karena sejarah munculnya kapitalisme adalah bergandengan dengan sejarah gereja dan sistem-sistem keagamaan.

Sebagai salah satu agama terbesar di dunia, Islam juga tidak luput menjadi objek penelitian Weber, walaupun penelitiannya berdasarkan fakta yang tidak lengkap. Yang menarik pendapat Marcel A. Boisard tentang Islam, ketika kaum Mukminin hidup menurut ajaran agama yang mendorong untuk berpikir dan memiliki akal yang kritis, Islam nampak sebagai pembawa obor kemajuan. Argumen-argumen yang diambil pada masa lampau tidak hanya ditarik sebagai apologi (mempertahankan agama) akan tetapi untuk menggugah kesadaran Islam. Pendekatan ini telah berhasil mempengaruhi rakyat jelata secara tidak terasa. Rencana-rencana umum yang dikemukakan oleh kaum reformis adalah bermacam-macam, memurnikan dari praktek-praktek agama dari unsur takhayul dan hal yang sudah tidak relevan lagi yang bertimbun-timbun sejak beberapa abad, membedakan yang pokok dan yang tidak pokok agar dapat memelihara dogma cara pemikiran yang merdeka. ${ }^{4}$

Menurut Bryan S. Turner, ada beberapa norma dalam Islam yang sering dikemukakan tokoh-tokoh pembaharuan dalam Islam, yaitu seperti asketisme, aktivisme dan tanggung jawab. Begitu juga sakralisasi kerja dengan formalisasi kerja adalah bagian dari ibadah yang juga identik dengan kerja keras yang dalam ajaran Calvinist diistilahkan dengan panggilan beruf yang harus dilaksanakan dalam kehidupan bergaya "askese duniawi" ${ }^{5}$

Banyak pemikir modern mengatakan, bahwa etika yang dijelaskan Weber tidak berbeda yang dipancarkan al-Qur'an, yang mengutamakan sikap jujur,

\footnotetext{
3 RH Tawney, Religion and the of Capitalism, (London: John Murray, 1964), hal. 100.

4 Marcel A Boisard, Humanisme dalam Islam; terjemahan oleh H.M. Rasjidi (Jakarta: N.V. Bulan Bintang, 1980), hal. 316.

5 Bryan S Turner, Sosiologi Islam: Suatu Telaah Analitis atas Tesa Sosiologi Weber; terjemahan GA Tocialu, (Jakarta: Rajawali Press, 1984), hal. 25-28.
} 
kerja keras, berperhitungan dan hemat dalam praktek etos kerja. Karena Weber juga pada dasarnya mengacu pada sejarah bisnis Muhammad SAW.

Al-Qur'an dan al-Hadis sebagai sumber dinamik memberi isyarat bahwa bekerja bagi setiap muslim adalah upaya yang sungguh-sungguh dengan menganugerahkan seluruh aset, pikiran dan dzikirnya untuk mengaktualisasikan atau menampakkan arti dirinya sebagai bagian dari masyarakat yang terbaik (khairuh ummah). ${ }^{6} \mathrm{Hal}$ ini kemudian menjadi dorongan terhadap suatu bangsa yang berasal dari sesuatu yang bersifat transendental sebagai suatu sikap hidup yang mendasar, yang dalam dunia Timur dianggap sebagai segala bentuk manivestasi dari daya kreasi manusia yang bertitik pangkal dari titik ketuhanan, yang nantinya akan tampak jelas dalam etos kerja. ${ }^{7}$

Islam suatu ajaran tidak berhenti pada suatu masa dan suatu lokasi geografis kultur. Senantiasa membuka diri dan tidak kaku dengan pengaruh-pengaruh dari luar. Dengan demikian Islam adalah ajaran yang dialogis. Dinamika yang ada menjadikan Islam sebagai agama yang bijaksana terhadap perubahanperubahan, selain itu menyerukan penganutnya untuk terus berkarya guna memperbaiki nasibnya sendiri. Jika tanpa karya maka ia sendirilah yang telah menghukum diri dengan keterbelakangan. Oleh karena itu mengapa Islam memerintahkan kepada pemeluknya supaya bekerja dan berusaha dipermukaan bumi ini, yaitu agar tercapai kesuksesan di dunia dengan tujuan mendapatkan anugerah atau karunia dari Allah SWT. Agama terbesar di dunia ini juga menjelaskan dalam sabda Nabi bahwa bekerja merupakan amal ibadah dan kewajiban bagi seorang muslim setelah kewajiban yang lain. Karena salah satu sebab yang memposisikan pekerjaan itu menjadi mulia adalah al-Qur'an menjadikan para Nabi dan Rasul sebagai pembawa risalah.

Sebagai agama yang tumbuh dan berkembang dalam lingkungan pedagang, Islam dalam ajarannya menolak pranata kependetaan yang merupakan pemberontakan terhadap polemik keagamaan, dan memprotes keras terhadap penyucian pola hidup kependetaan sebagai mahkota takwa. Agama ini telah menjelaskan prinsip-prinsip agama yang menyatakan keesaan dan keagungan

6 Toto Tasmara, Etos Kerja Pribadi Muslim, (Yogyakarta: Dana Bhakti Wakaf, 1995), hal. 27.

7 Abd. Munir Mulkhan, Bisnis Kaum Sufi: Studi Tarekat dalam Masyarakat Industri, (Yogyakarta: Pustaka Pelajar, 1998), hal. 119. 
Allah. ${ }^{8}$ Hal ini memperjelas bahwa Islam bukan hanya serangakaian agama yang harus diyakini, tapi juga menghendaki usaha, perjuangan, pergerakan dan rekonstruksi dari unsur-unsur perubahan sosial. Agar kebutuhan hidup terpenuhi, mereka tidak mau menyia-nyiakan sedetik waktu pun demi kepentingan bisnis dan pedagangan, menggarap lahan pertanian, perkebunan dan sebagainya untuk menciptakan etos kerja yang maksimal. Meskipun sesungguhnya al-Qur'an menjelaskan bahwa hilangnya waktu sedikit untuk beribadah tidak akan mengurangi produktivitas karena ibadah melatih disiplin dan tanggung jawab. Allah sendiri menjanjikan akan mengganti hilangnya waktu itu dengan memberinya kecukupan, dengan syarat jika manusia mempunyai kehendak, prakarsa, dan karya yang mendukung untuk itu, ia akan memberi jalan melalui kekuasaan politik, perdagangan, pertanian dan industri. ${ }^{9}$ Agama ini memberikan padangan hidup yang sangat tegas merekonstruksi sebuah kehidupan seperti yang terlihat al-Qur'an dan al-Hadis.

Agar terwujudnya perubahan sosial ke arah perkembangan perekonomian suatu bangsa, perlu masyarakat yang berjiwa sosial dibidang wirausaha. Mc Clelland sebagai seorang psikologi ingin membuktikan pada masyarakat, semangat berprestasi mendorong modernisasi di negara-negara berkembang. Sehingga perkembangan ekonomi antar bangsa dikehendaki dengan tingkah laku atau etos kerja seorang wirausahawan. Konsep tingkah laku kewirausahaan sebagai pengambil resiko yang moderat, pengetahuan terhadap keputusan-keputusan yang diambil, mengetahui terlebih dahulu terhadap kemungkinan-kemungkinan yang bakal terjadi, penuh semangat dan memiliki keterampilan berorganisasi. ${ }^{10}$

Tidak dapat dipungkiri, apa yang pernah dilakukan para antropolog, sosiolog dan psikolog diatas dapat saja berbeda jika diterapkan pada masyarakat dengan setting budaya yang berbeda. Namun juga tidak menutup kemungkinan akan sama hasilnya, sekalipun setting budaya, sosiologis, dan geografisnya berbeda. Dengan demikian dapat disimpulkan bahwa agama dan budaya memang memiliki peran yang cukup banyak dalam menumbuhkan semangat ker-

8 Muhammad Yusuf Musa, Islam: Suatu Kajian Komprehensif; terjemahan oleh A. Malik Madaniy dan Hamim, (Jakarta: Rajawali, 1988), hal. 12.

9 Zakiyuddin Baidhawy, Islam Melawan Kapitalisme! Konsep-Konsep Keadilan dalam Islam, (Yogyakarta: Resist Book, 2007), hal. 97.

10 Nanat Fatah Natsir, Etos kerja Wirausahawan Muslim, (Bandung: Gunung Djati Press, 1999), hal. 2. 
ja dikalangan pengusaha muslim dalam meningkatkan produktifitas. Karena etos kerja pada hakikatnya merupakan bagian dari suatu kebudayaan, sebagai suatu proses menghadapi dan menjawab tantangan yang dihadapkan pada manusia. Etos kerja dibentuk oleh suatu proses kebudayaan yang panjang, yang kemudian membentuk suatu kepribadian. Jika suatu masyarakat tertentu mempunyai etos kerja yang berbeda, hal itu disebabkan oleh proses panjang kebudayaan dan tantangan yang berbeda yang dihadapkan padanya, serta perbedaan dalam memberikan jawaban atas tantangan itu. ${ }^{11}$

Bisnis dianggap sebagai sebuah medan pertempuran. Terjun ke dunia bisnis berarti siap untuk bertempur habis-habisan dengan sasaran akhir memperoleh keuntungan, bahkan keuntungan yang sebesar-besarnya. Hal ini yang sangat fundamental dalam kegiatan bisnis. Namun bukan berarti memperoleh keuntungan yang sebesar-besarnya tidak membutuhkan etika. Justru etika yang sangat relevan serta mempunyai tempat yang sangat strategis. Etika merupakan pengejawantahan prinsip-prinsip ajaran Islam yang bersumber pada al-Qur'an dan al-Hadis.

Ibnu Khaldun pernah meneliti jenis-jenis mata pencaharian yang banyak dilakukan oleh masyarakat Islam, yang disimpulkan terdiri atas pertanian, industri, perdagangan, perburuhan dan perikanan. Ia membagi petani menjadi dua kelompok, yaitu peternak dan petani. Kemudian membagi industri menjadi tiga kelompok, pertama kerajinan tangan seperti menenun, pertukangan dan besi. Kedua, pemikiran seperti puisi, pendidikan dan musik. Ketiga, politik dan hal-hal dengan hukum dan peraturannya. ${ }^{12}$

Ciri-ciri masyarakat Islam yang dijelaskan oleh Ibnu Khaldun diatas, terdapat pula pada Suku Bugis yang menjadi masyarakat Nunukan Kalimantan Utara, pada kriteria perdagangan dan pengusaha. Dan yang sangat menarik dari kehidupan Suku Bugis adalah selain dikenal sebagai pedagang, saudagar, pengusaha, sejak zaman dulu juga orang Bugis mempunyai tradisi merantau (bermigrasi) yang sangat kuat, biasanya ketika mereka telah memasuki suatu daerah, mereka langsung menguasai pasar, sehingga hal ini diyakini sebagai faktor yang menyebabkan mereka dapat bersaing dengan etnik lainnya. Ketika

11 Musa Asy'arie, Islam Etos Kerja dan Pemberdayaan Umat, (Yogyakarta: LESFI \& IL, 1997), hal. 54 .

12 Ibn Khaldun, Muqaddimah; terjemahan Ahmadie Thoha, (Jakarta: Pustaka Firdaus, 2000), hal. 447-454. 
mereka melakukan migrasi ke daerah-daerah lain di Kalimantan maupun di luar Kalimantan, pola atau sistem kehidupan orang Bugis tersebut kemudian berkembang, misalnya dalam bisnis yang bergerak pada bidang industri, transportasi, perhotelan, perkapalan, dan sekaligus pemilik perusahaan, baik yang tergolong perusahaan besar, menengah dan kecil.

Sebagai pedagang dan pengusaha yang gemar merantau, ini menjadikan mereka relatif lebih berhasil dan sukses diperantauan bila dibandingkan dengan pedagang asli daerah tersebut. Ini memiliki beberapa faktor alasan sehingga mereka mampu bersaing secara gigih. Selain aktif dalam menjalankan kegiatan sebagai pedagang dan pengusaha, orang Bugis juga terkenal taat dalam menjalankan ibadahnya. Hal ini dilatarbelakangi budaya suku Bugis dominan berasal dari kelompok muslim baik santri maupun sekolah umum yang paham dengan ajaran agamanya. Dengan kepahaman itu mendorong semangat mereka untuk melaksanakan ibadah haji. Temuan lain memperlihatkan bahwa salah satu watak orang Bugis adalah "watak dagang" yaitu watak yang selalu memperhitungkan "untung rugi" dalam sikap dan tindakan.

Selanjutnya akan dikembangkan suatu kajian yang khusus mengenai uraian yaitu ekonomi Islam dilihat dari aspek budaya etos kerja masyarakat Suku Bugis yang berada di Kabupaten Nunukan Kalimantan Utara, yang dimana budaya merupakan roda kehidupan etnis Bugis walaupun tidak terlepas dari pada paham kegamaan mereka, dalam hal ini agama Islam.

Dengan penelitian secara khusus diharapkan akan didapatkan suatu studi yang lebih mampu menampilkan nilai-nilai qur'ani pada aspek budaya. Penelitian ini merupakan keinginan untuk mencoba menggali sejauh mana nilai-nilai tersebut yang secara determin membawa perubahan sosial, khususnya dalam persoalan pelaku bisnis. Karena masih jarang penulis melihat penelitian yang membahas ekonomi Islam, secara khusus yang dijelaskan pada aspek budaya masyarakat setempat.

Penelitian ini mengambil lokasi di Kabupaten Nunukan Kalimantan Utara dengan alasan; tokoh non formal, tokoh intelektual dan tokoh masyarakat dari Suku Bugis lebih berkembang berdomisili di Kabupaten ini dari pada di daerah lain. Di sisi lain Kabupaten ini menjadi pusat penyebrangan atau transportasi yang sangat mudah ke negara Malaysia. Sehingga Suku Bugis sangat kreatif memiliki inisiatif untuk berdagang dan menjadi warga di Kabupaten Nunukan. 


\section{B. Agama \& Budaya Masyarakat dan Etos Kerja Islam serta Pebisnis Muslim}

\section{Agama \& Budaya Masyarakat}

Diskusi soal agama akan semakin menarik, karena disertai harapan yang sangat berlebihan. Harapan demikian menginginkan agama sebagai paradigma alternatif dalam membingkai peradaban manusia di masa depan. Agama tampil sebagai bahan diskusi atau perbincangan yang mewarnai perjalanan sejarah manusia dalam epilog abad ke-21 ini.

Dari sekian banyak definisi tentang agama, yang paling mencakup dan mencerminkan realitas semua agama adalah seperti yang di ajukan Erich Fromm, agama baginya adalah "setiap sistem pemikiran dan tindakan yang secara bersama-sama dianut oleh sekelompok orang yang memberikan kepada individu, suatu kerangka orientasi dan objek pengabdian". ${ }^{13}$ Berdasarkan definisi ini, tidak ada suatu kebudayaan pun di masa lampau dan juga tampaknya di masa depan yang tidak mengandung agama. Tidak seorang pun yang tidak mempunyai kebutuhan religius, suatu kebutuhan akan suatu kerangka orientasi dan objek pengabdian. Pandangan di atas sejalan dengan asumsi dasar Islam tentang kecenderungan manusia untuk selalu mencari dan menciptakan "Ilah" atau suatu sesembahan secara sadar atau tidak. ${ }^{14}$

Seperti halnya kebudayaan, agama juga merupakan sistem pengarahan yang tersusun dari unsur-unsur normatif yang membentuk jawaban umatnya pada berbagai tingkat pemikiran, perasaan dan perbuatan. Ia membuat manusia menerima, merasakan dan memikirkan serta melaksanakan dengan caracara yang diinginkan. ${ }^{15}$

Agama mempunyai pengaruh besar terhadap kebudayaan suatu komunitas. Agama diatas kebudayaan. Sikap ini menunjukkan adanya suatu keterikatan antara agama dan kebudayaan. Hidup dan kehidupan manusia harus terarah pada tujuan ilahi dan insani; manusia harus mempunyai dua tujuan sekaligus. Nilai-nilai dan idealisme agama akan mempengaruhi suatu kebudayaan. Hal ini mulai dari arsitektur sampai pada tata politik. Mengatur ber-

\footnotetext{
13 Lihat Damam Rahardjo, Islam dan Transformasi Sosial, (LSAF, Jakarta: 1999), hal. 301.

${ }^{14}$ Ibid.

15 Nanat Fatah Natsir, Etos Kerja Wirausahawan Muslim, hal. 24.
} 
bagai segi mulai dari sains dan perdagangan. Sebaliknya, terkadang budaya mempengaruhi praktek agama yang ada walau tidak sampai mengubah inti dari ajaran agama yang ada.

Aspek penting dari agama adalah berkaitan dengan yang sakral. Durkheim menyatakan bahwa manusia selalu membedakan dua hal yang berlawanan, yaitu sakral dan profane. ${ }^{16}$ Dengan demikian perilaku agama tidak dapat didefinisikan diluar konteks kebudayaan atau lingkungan agamanya. Tatkala suatu masyarakat berubah dari agraris ke industri, bisa jadi agamanya pun mengalami perubahan. Pemahaman atas agama menjadi penting karena ia mengkondisikan dan mengekspresikan nilai-nilai masyarakat secara keseluruhan.

Secara praktis, di dalam pemahaman kita tentang budaya adalah adanya kandungan utama yang berkaitan dengan persepsi terhadap nilai dan lingkungannya yang melahirkan makna dan pandangan hidup, yang akan mempengaruhi sikap dan tingkah laku. Sikap dan tingkah laku (termasuk bahasa) hasil karsa dan karya, termasuk segala instrumentnya, sistem kerja, teknologi. Dalam proses budaya terdapat saling mempengaruhi dan saling ketergantungan (interdepedensi), baik sosial maupun nonsosial. ${ }^{17}$

Setiap etnik yang ada, mempunyai kebudayaan yang menjadi warisan dari pada keturunan internal sukunya. Sistem pemikiran dan tindakan yang secara bersamaan dianut oleh sekelompok orang yang memberikan kepada individu, suatu kerangka orientasi dan objek pengabdian. Perintah agama sekaligus kebudayaan pada suatu etnik atau suku pasti mempunyai ciri khas tersendiri untuk mencapai kelangsungan hidupnya. Ketika orang berbicara bahwa disatu sisi kerja adalah ibadah yang bisa diidentikkan dengan kerja adalah "panggilan", maka pada sisi lain agama sebagai salah satu unsur inti dalam kehidupan dan akan membantu manusia. Agama merupakan transformasi simbolik pengalaman. Dan kebudayaan merupakan faktor pendorong pada internal suatu komunitas tertentu. Rancangan yang diberikan terhadap kehidupan dianggap orang beragama sebagai suatu penyelamatan natural atau supranatural. ${ }^{18}$

Masalah keagamaan dan kebudayaan setiap suku juga akan mempengaruhi proses perkembangan kehidupan manusia terutama dalam masalah hu-

16 Betty R. Schart, The Sociological Study of Religion, terjemahan Drs. Machnun Husein, Kajian Sosiologi Agama, (Yogyakarta: Tiara Wacana, 1995), hal. 63-64.

17 Toto Tasmara, Membudayakan Etos Kerja Islam, (Jakarta; Gema Insani Press, 2000), hal. 161.

18 Nanan Fatah Natsir, Etos Kerja Wirausahawan Muslim, hal. 23. 
manistik, moral, etika dan estetika dalam etos kerja. ${ }^{19}$ Sumber inspirasi budaya Islam adalah al-Qur'an dan Sunnah Rasulullah SAW. yang diikat dalam satu kata, yaitu akhlaq. Sebagaimana Rasulullah di utus untuk menyempurnakan akhlaq manusia dan pada diri beliau terdapat contoh teladan yang sangat besar, yaitu akhlaq yang mulia. ${ }^{20}$

\section{Etos Kerja Islam}

Etos kerja sangat mempengaruhi kinerja pengusaha muslim. Karena dunia kerja tidaklah semata-mata bergerak di wilayah tubuh atau berhubungan dengan benda-benda saja yang bersifat duniawi semata, tetapi juga bergerak di wilayah batin, yang berhubungan dengan nilai-nilai dan berdimensi ukhrawi. Ini akan sangat berpengaruh dalam meningkatan produktifitas bisnis para pekerja.

Beekun menjelaskan ada beberapan kunci atau prinsip dalam berbisnis yang harus dijalani kaum muslim. Pertama jujur dan berkata benar. Kejujuran dan kebiasaan berkata benar adalah kualitas-kualiatas yang harus dikembangkan dan dipraktekkan oleh para penguasa muslim. Kebenaran misalnya, memiliki pengaruh penguatan diri. Dalam sebuah hadist menjelaskan bahwa "berkata benar dapat membawa kebaikan, dan kebaikan akan membawa kepada surga. Sedangkan kebohongan akan membawa kepada al-fujur (misalnya kejahatan dan berbagai perbuatan setan). ${ }^{21}$

Perbuatan ini sangat penting bagi pengusaha muslim karena adanya kebutuhan untuk mendapatkan keberuntungan dan godaan untuk memperbesar kemampuan produk dan jasa mereka selama puncak penjualan. Maka dari itu Rasulullah berkata, bahwa "para pedagang akan dibangkitkan di hari pembalasan sebagai orang-orang yang melakukan kejahatan, kecuali mereka yang takut kepada Allah SWT, jujur dan berkata benar. ${ }^{22}$ Kedua, sebagai seorang pengusaha muslim harus menepati janji, dalam sebuah hadist menerangkan, bahwa "jika engkau memberi jaminan kepada ku mengenai 6 hal, aku akan menjami engkau surga. Berkata benar bila berkata-kata, menepati janji yang

19 Tobroni dan Syamsul Arifin, Islam Pluralisme Budaya dan Politik: Refleksi Theologi Untuk Aksi dalam Keberagaman dan Pendidikan, (Yogyakarta: SIPRESS, 1994), hal. 5.

20 Q.S. al-Qalam (68): 4.

${ }^{21}$ H.R. Sahih al-Bukhari. No. 8.166.

${ }^{22}$ H.R. Tirmidhi, Ibn Hajjah, Darimi \& Baihaqi. 
telah engkau perbuat, menjaga amanah, menghindari immortalitas seksual, merendahkan mata, dan menjaga kedua tanganmu dari ketidakadilan. ${ }^{23}$ Ketiga, mencintai Allah lebih dari perniagaanmu. Apapun yang kita kerjakan kita harus bersandar sepenuhnya kepada Allah sebagai bentuk kecintaan kita kepadanya, dalam artian setiap langkah dan kinerja kita hanya karena-Nya. Allah telah mengingatkan, jika seluruh keluargamu, bahkan seluruh hartamu lebih kamu cintai daripada Allah SWT dan Rasul-Nya, maka tunggulah sampai Allah mendatangkan keputusan-Nya. Dan Allah tidak memberi petunjuk kepada orangorang fasik. ${ }^{24}$ Keempat, tidak terlibat dalam kecurangan. Seorang muslim harus memperlakukan orang lain dengan cara yang sama dan adil tanpa mengurangi takaran sedikit pun. ${ }^{25}$ Kelima, seorang pebisnis muslim tidak boleh melakukan suapan. Kadangkala pengusaha muslim memberi baqshish untuk mendesak pihak lain agar memberi mereka kesempatan khusus untuk memungkinkan mereka mendapat peluang dengan praktek-praktek ketidakjujuran. ${ }^{26}$

Menurut Toto Tasmara, ciri-ciri orang yang mempunyai karakter etos kerja yang baik dalam Islam antara lain menghargai waktu, bermoral bersih, menjunjung tinggi kejujuran, mempunyai komitment yang kuat, dan istiqomah dalam bekerja. ${ }^{27}$ Ciri ini hanyalah sebagian dari ciri-ciri yang ada dalam Islam, karena sedemikian banyaknya ciri-ciri bagi orang yang mempunyai etos kerja yng berlandaskan nilai-nilai Islam.

Secara sederhana, etos dapat dipahami sebagai sebuah karakter nilai yang mentransformasikan diri ke alam duninya. Atau karakter dan sikap dasar manusia terhadap diri dan dunianya. Ia merupakan aspek evaluatif yang memberi penilaian atas berharga tidaknya sesuatu serta memberi orientasi atas tindakan manusia, yang tercermin dalam sikap dan pilihan-pilihan yang dikembangkannya. ${ }^{28}$

${ }^{23}$ Ubadah ibn al-Samit, Ahmad \& Baihaqi, dalam Mishkat al-Masabih, 4870.

24 Q.S. at-Taubah (9): 24.

25 Q.S. al-Muthaffifin (83): 1-4.

26 Nash, Laura, Ethic Without the Sernon, dalam Peter Marsden dan Jang Shafritz (eds) Essential Business Ethics, (New York: Penguin), hal. 38-61. Yang dikutip dalam buku Rafik Issa Beekun, Islamic Business Ethics, (Herndon, Virginia, U.S.A: International Institute of Islamic Thought, 1997), hal. 64-70.

27 Toto Tasmara, Membudayakan Etos Kerja Islam, hal. 87-89.

28 Yudi Latif, Menyemai Karakter Bangsa: Budaya Kebangkitan Berbasis Kesastraan, (Jakarta: Kompas, 2009), hal. 149. 


\section{Pebisnis Muslim}

Entrepreneur muslim merupakan manusia yang bertujuan mendapatkan keperluan kehidupannya melalui usaha perniagaan dan seterusnya memberikan kemanfaatan kepada masyarakat melalui perniagaan. ${ }^{29}$

Aspek bisnis Muhammad SAW ini juga luput dari perhatian kebanyakan orientalis. Mungkin karena dianggap kurang kontroversial dan tidak menarik dalam perdebatan teologis. Sebagian dari mereka juga sering melancarkan serangan terhadap pribadi Muhammad SAW tetapi jarang sekali yang mengkaji secara mendalam perilaku bisnis beliau. ${ }^{30}$ Muhammad SAW merupakan figure yang tepat dijadikan sebagai teladan dalam bisnis dan perilaku ekonomi yang baik.

Afzalurrahman dalam bukunya Muhammad as a Trader mencatat bahwa setelah menikah Muhammad SAW tetap melangsungkan usaha perdagangannya seperti biasa. Namun beliau telah bertindak sebagai manajer sekaligus mitra dalam usaha istrinya (Khadijah). Untuk melakukan suatu perdagangan tersebut, Muhammad melakukan berbagai pusat perdagangan di seluruh penjuru negerinya dan negeri-negeri tetangga. ${ }^{31}$

Memang tidak banyak catatan sejarah yang merekam usaha perdagangan dan perjalanan bisnis yang dilakukan Muhammad SAW setelah nikah. Tetapi sebagaimana yang dinyatakan Afzalurrahman lebih lanjut, terdapat catatan tentang hubungan dagang beliau dengan berbagai macam orang. Hal ini memberi petunjuk bahwa Muhammad SAW benar-benar menggeluti bidang perdagangan, untuk lebih kongkretnya, sifat-sifat dasar dalam prophetic values of business and management meliputi sifat adil, jujur, amanah (terpercaya), fathanah (memiliki pengetahuan luas), tabligh (komunikatif) dan syaja'ah (berani). ${ }^{32}$

Sejarah Muhammad SAW merupakan sejarah yang patut di jadikan pedoman dan refrensi hidup dalam berbisnis. Kuntowijoyo dalam bukunya Identitas Politik Umat Islam mencatat bahwa kesadaran sejarah merupakan keterlibatan secara aktif dalam sejarah, berarti kesadaran kenabian atau kesadaran profetik. ${ }^{33}$

29 Muhammad Nejatullah Siddiqi, Perusahaan Ekonomi dalam Islam, (Kuala Lumpur: Zizi Press, 1988), hal. 123.

30 Ibid.

31 Afzalurrahman, Muhammad Sebagai Seorang Pedagang (Muhammad as A Trader), (Jakarta: Yayasan Swarna Bhumy, 1997), hal. 12.

32 Ibid.

33 Kuntowijoyo, Identitas Politik Umat Islam, (Bandung: Mizan, 1997), hal. 38. 


\section{Temuan dan Hasil}

Penelitian ini menggunakan analisis kualitatif yang terutama lebih menggunakan kata-kata daripada angka-angka. Menurut Miles dan Huberman, kata-kata lebih padat dibanding angka-angka dan biasanya memiliki makna ganda, apalagi banyak kata-kata yang hanya akan bermakna setelah melihat latar belakang atau dihubungkan dengan kata lain. ${ }^{34}$

Adapun pendekatan yang peneliti lakukan dalam metode ini adalah pendekatan fenomenologis yang mana pendekatan ini berusaha untuk memahami arti peristiwa dan kaitannya terhadap orang - orang bisaa dalam situasi - situasi tertentu, dan dalam pendekatan ini peneliti diharuskan untuk berprinsip tidak mengetahui arti sesuatu bagi orang - orang yang sedang diteliti. Jadi dalam hal ini peneliti diharapkan menjadi orang asing yang benar benar objektif dan tidak dalam posisi mempunyai persepsi terhadap objek yang sedang diteliti. Untuk langkah-langkah analisis data adalah pengkodean, penyusunan matriks, pengisian indeks peristiwa, dan pengujian kesimpulan. ${ }^{35}$

Secara kasar ruang lingkup penelitian ini di Kabupaten Nunukan dengan meliputi Kecamatan Nunukan dan Kecamatan Sebatik, yang dimana dua kecamatan tersebut tempat bermukim dan mayoritas masyarakat Suku Bugis. Suku yang memiliki profesi pebisnis atau pengusaha ini, dalam menjalankan bisnisnya masih tetap dalam pengaruh agama dan budaya.

Eksistensi mereka di Kabupaten Nunukan Kalimantan Utara, sebelumnya ada sejarah hijrah tahun 60an masa pemberontakkan Kahar Mudzakkar dan DI/TII. Banyak yang hijrah dari Sulawesi Selatan karena ingin melindungi diri, sampai ke Negara Malaysia. Ada yang menjadi TKI dan tenaga buruh. Pada masa akhir perselisihan Indonesia dan Malaysia, Suku Bugis akhirnya menyebar dan membuka lahan di Kecamatan Sebatik Kabupaten Nunukan, sampai memiliki keturunan dan menjadi warga setempat.

34 Miles, Matthew B. dan A. Michael Huberman, Qualitative Data Analysis; terjemahan Tjejep Rohendi Rohidi, (Jakarta: UI Press, 1992), hal. 62

35 Ibid. 


\section{Pengaruh Agama Terhadap Etos Kerja Masyarakat Suku Bugis di Kabu- paten Nunukan Kalimantan Utara}

Dasar pengkajian kembali makna Etos Kerja di Eropa diawali oleh buah sejarah Muhammad SAW dan hasil riset Max Weber. Salah satu unsur dasar dari kebudayaan modern, yaitu rasionalitas (rationality) menurut Weber lahir dari etika Protestan yang secara ekplisit dikaji menggunakan metode sejarah Muhammad SAW. Pada dasarnya agama merupakan suatu sistem nilai. Sistem nilai ini tentunya akan mempengaruhi atau menentukan pola hidup para penganutnya. Cara berpikir, bersikap dan bertindak seseorang pastilah diwarnai oleh ajaran agama yang dianutnya jika ia sungguh-sungguh dalam kehidupan beragama. Dengan demikian, kalau ajaran agama itu mengandung nilai-nilai yang dapat memacu pembangunan, jelaslah bahwa agama akan turut menentukan jalannya pembangunan atau modernisasi. Dalam etos kerja Suku Bugis sangat memperkuat nilai-nilai agama. Seperti pengakuan H. Bahar, H. Ramli, H. Batto, H. Hafid dan H. Sabri warga Kecamatan Nunukan dan Kamal, H. Andeng, H. Nuwardi Kecamatan Sebatik, bahwa dari Nabi kita diajarkan berbagai kiat-kiat dalam berdagang. Jujur, amanah, istiqomah, serta rukun Iman dan rukun Islam meruapakan hal yang terpenting bagi kehidupan Suku Bugis.

Dalam al-Qur'an sangat menantang sikap malas dan menyia-nyiakan waktu, baik dengan cara berpangku tangan dan tinggal diam atau melakukan hal-hal yang tidak produktif. Orang yang tidak mempergunakan waktunya secara baik akan dicela dan dimasukkan pada golongan orang-orang yang sangat merugi. ${ }^{36}$

Seperti yang dijelaskan oleh $\mathrm{H}$. Marhabang, adalah sesuatu yang tidak bisa disangkal bahwasanya semua bentuk hasil produksi adalah hasil daripada sebuah kerja keras Suku Bugis yang ada di Kabupaten Nunukan. Dan setiap perkembangan dalam hal kualitas dan kuantitas produksi juga sangat tergantung pada sebuah kerja. Maka makna penting kerja dan amal itu tidak akan pernah tidak ditekankan. Agama selalu menyerukan pada setiap orang untuk selalu bekerja dan bejuang, serta melarang segala bentuk praktek kemalasan dan berpangku tangan. ${ }^{37}$

36 Q.S. al-Ashr': 1-3.

37 Wawancara dengan H. Marhabang di Nunukan, tanggal 3 April 2013. Ia seorang pedagang kaki lima. 


\section{Pengaruh Budaya Terhadap Etos Kerja Masyarakat Suku Bugis di Kabu- paten Nunukan Kalimantan Utara}

Selain temuan Rosmiani diatas, Usman Pelly (dalam Rahimah) mengatakan bahwa sikap, mental, tekad, disiplin dan semangat kerja masyarakat juga disebut sebagai etos budaya dan secara operasional, etos budaya ini juga disebut sebagai etos kerja. Kualitas etos kerja ini ditentukan oleh sistem orientasi nilai budaya masyarakat yang bersangkutan. Masyarakat yang memiliki sistem nilai budaya maju akan memiliki etos kerja yang tinggi dan sebaliknya, masyarakat yang memiliki sistem nilai budaya yang konservatif akan memiliki etos kerja yang rendah, bahkan bisa sama sekali tidak memiliki etos kerja. Pernyataaan ini juga didukung oleh studi yang dilakukan Suryawati, Dharmika, Namiartha, Putri dan Weda yang menyimpulkan bahwa semangat kerja/Etos Kerja sangat ditentukan oleh nilai-nilai budaya yang ada dan tumbuh pada masyarakat yang bersangkutan. Etos kerja juga sangat berpegang teguh pada moral etik dan bahkan Tuhan. Etos kerja berdasarkan nilai-nilai budaya dan agama ini menurut mereka diperoleh secara lisan dan merupakan suatu tradisi yang disebarkan secara turun-temurun. ${ }^{38}$

Ciri etos kerja pengusaha muslim Suku Bugis, selain kerja keras, berani dan ulet, orang Bugis juga memiliki jiwa entreprenuership serta menciptakan lapangan pekerjaan yang dibaluti dengan kejujuran juga merupakan hal sangat signifikan dalam melakukan dan menjalani suatu usaha. Suku bugis memiliki jiwa pekerja yang tinggi, yaitu kesadaran dan kemampuan yang sangat mendalam untuk melihat segala fenomena yang ada disekitarnya, merenung, dan kemudian bergelora semangatnya untuk mewujudkan setiap perenungan batinnya dalam bentuk yang nyata dan realistis. Dalam arti cerdas dalam melihat peluang, seperti sosok dan pernyataan Pak Kamal Soeryanto. Nurani yang sangat halus dan tanggap terhadap lingkungan dan setiap tindakan diperhitungkan dengan laba rugi, manfaat atau mudharat (entrepreneurship). ${ }^{39}$

Orang yang memiliki jiwa pengusaha adalah mereka yang selalu melihat setiap sudut kehidupan dunia sebagai peluang. Berpikirnya sangat analitis, melihat segala sesuatu dalam gambar yang besar. Tidak ada yang bisa mengira

38 Artikel Ferry Novliadi, Hubungan Antara Organization-Based Self-Esteem Dengan Etos Kerja, (Sumatera Utara: Universitas Sumatera Utara), hal. 10.

39 Toto Tasmara, Membudayakan Etos Kerja Islam, hal. 107. 
dizaman anak-anaknya hanya berjualan cemilan di pelabuhan akan menjadi pengusaha sukses dikemudian hari. Semua dimulai dari melihat kesempatan dan kemudian berani mencoba. Seperti yang telah dipraktekkan oleh orangorang Bugis, selain memiliki jiwa pengusaha, berani memulai dalam mengambil keputusan. Ini telah dijalani oleh H. Nuwardi di Kecamatan Sebatik. Integritas yang tinggi membuat usahanya berjalan dengan lancar pada negara Fhilipina. Karena pada awalnya, ia dikenal oleh masyarakat seorang tukang ojek dan kini menjadi pengusaha besar yang sukses. ${ }^{40}$

Seperti yang dirasakan oleh H. Muh. Ali Karim. Ia mendapatkan gelar Honoris Causa ${ }^{41}$ dari salah satu perguruan tinggi di Jakarta, karena bisa berdagang memainkan harga antara Sebatik - Tarakan - Tawau (Malaysia). Pernyataan ini dibenarkan oleh beberapa penduduk di Kecamatan Sebatik. ${ }^{42}$ Semua itu karena Suku Bugis masih memegang prinsip tadi, "resopa temmangingi namallomo naletei pammase dewata" bermakna "hanya kerja keras dan sungguh-sungguh yang mendapat rahmat dari dewata/yang maha kuasa.

Sikap kerja keras, tangguh, dan ulet akan tumbuh jika kita tetap istiqamah. No pain no gain, no free lunch for such a thungs, no deal no venture; begitulah para eksekutif memiliki semboyan dalam usahanya, tidak ada sesuatu yang kita capai kecuali dengan pengorbanan yang sungguh-sungguh untuk meraihnya. Joe Paterno berkata, "disamping kebanggaan, loyalitas, disiplin, pikir dan dzikir, percaya diri merupakan kunci untuk membuka semua pintu yang terkunci". ${ }^{43}$

Begitulah yang ditradisikan oleh nenek moyang Suku Bugis, budaya kerja keras sebagai pertalian harga diri adalah sikap yang telah mentradisi dan mengakar begitu kuat dalam kehidupan budaya mereka, sebagai warisan leluhur dan nenek moyang mereka berdagang sekaligus pelaut. Budaya malu

40 Observasi Lapangan tanggal 5 April 2013, pukul 17.28.

${ }^{41}$ Gelar Honoris Causa (H.C) / Gelar Kehormatan adalah sebuah gelar kesarjanaan yang diberikan oleh suatu perguruan tinggi/universitas yang memenuhi syarat kepada seseorang, tanpa orang tersebut perlu untuk mengikuti dan lulus dari pendidikan yang sesuai untuk mendapatkan gelar kesarjanaannya tersebut. Gelar Honoris Causa dapat diberikan bila seseorang telah dianggap berjasa dan atau berkarya luar biasa bagi ilmu pengetahuan dan umat manusia. Sumber http://id.wikipedia.org bebas, diakses tanggal 17 Juni 2013, pukul 23.44.

${ }^{42} \mathrm{H}$. Muh. Ali Karim merupakan pengusaha yang mampu memainkan perdagangan dengan baik dan ulet di Kalimantan Timur berhubungan dengan Negara Malaysia. Ia berdarah Bugis Soppeng Wajo.

43 Toto Tasmara, Membudayakan Etos Kerja Islam, hal. 128. 
juga di kalangan Suku Bugis menunjukkan satu pola yang menjadi darah daging kesukuan sebagai seorang pengusaha muslim yang sejatinya mengikuti jejak Muhammad SAW.

\section{Kesimpulan}

Pengaruh agama dalam etos kerja seorang pengusaha sangat berperan besar. Tanpa agama bisnis tidak akan berjalan dengan baik. Jikapun ada yang menemukan kasus seorang pengusaha tidak pernah menjalankan sesuai hukum agama, mustahil walaupun sedikit tidak memiliki nilai-nilai agama, tidak sempurna sekalipun. Hanya terkadang terletak pada persoalan paham dan tidaknya teori yang dipraktekkan dalam berbisnis.

Seperti kasus sesuai penelitian ini, bahwa agama menjadi pondasi dari Suku Bugis dalam menjalankan bisnisnya, baik bisnis kelas bawah, menengah, dan atas. Nilai-nilai agama yang dipraktekkan zaman Rasulullah sangat menjadi acuan. Keuletan, kejujuran, disiplin, dan bershodaqoh ini menjadi rutinitas wajib di tiap bulannya atau setiap penghasilan perbulannya. Tidak hanya dikarenakan mereka seluruhnya seorang muslim, bahkan pebisnis ala Nabi telah menjadi budaya dari Suku Bugis yang ada di Kalimantan Timur. Profesi bisnis telah ditradisikan sejak nenek moyang Suku Bugis, budaya kerja keras sebagai pertalian harga diri adalah sikap yang telah mentradisi dan mengakar begitu kuat dalam kehidupan budaya mereka, sebagai warisan leluhur dan nenek moyang mereka berdagang sekaligus pelaut.

Jadi, pengaruh agama dan budaya pebisnis muslim Suku Bugis sangat berpengaruh dalam aktifitas bisnis mereka. Satu yang sedikit menarik dalam penelitian ini, bahwa adanya rasa malu keluar rumah jika Suku mereka tidak bekerja dan berproduksi. Sehingga banyak dari mereka setelah lulus sekolah, selesai kuliah, sudah dipikirkan apa aktifitas sebelumnya. Apakah menjadi pegawai honor sembari membantu bisnis orang tua atau bisnis keluarga, yang jelas judul dari pada kehidupan Suku Bugis tidak menganggur dan beraktifitas masih sesuai dengan garis nilai agama dan budaya. 


\section{DAFTAR PUSTAKA}

Abdullah, Irwan. 1994. The Muslim Businessmen of Jatinom (Religious Reform and Economic Modernization in a Central Javanese Town); Disertasi Doktor diterbitkan. University van Armsterdam.

Mubyarto dkk. 1992. Etos Kerja dan Kohesi Sosial Masyarakat Sumba, Rote, Sabu, dan Timor Provinsi Nusa Tenggara Timur; Cet. II. Yogyakarta: P3K-UGM. . 1988. Sistem Dan Moral Ekonomi Indonesia. Jakarta: LP3ES.

Mulkhan, Abd. Munir. 1998. Bisnis Kaum Sufi: Studi Tarekat dalam Masyarakat Industri. Yogyakarta: Pustaka Pelajar.

Afzalurrahman. 1997. MUHAMMAD Sebagai Seorang Pedagang. Jakarta: Yayasan Swarna Bhumy.

Antonio, Muhammad Syafii. 2007. Muhammad SAW: The Super Leader Super Manager. Jakarta: Tazkia Multimedia.

Asy'arie, Musa. 1997. Islam Etos Kerja dan Pemberdayaan Umat. Yogyakarta: LESFI \& IL.

Baidhawy, Zakiyuddin. 2007. Islam Melawan Kapitalisme! Konsep-Konsep Keadilan dalam Islam. Yogyakarta: Resist Book.

Bellah, Robert N. 1992. Religi Tokugawa: Akar-akar Budaya Jepang; terjemahan Wardah Hafidz dan Wiladfi Budiharga. Jakarta: Gramedia Pustaka Utama.

Beekun, Rafik Issa. 1997. Islamic Business Ethics. Herndon, Virginia, USA: zafar Sdn. Bhd.

Boisard, Marcel A. 1980. Humanisme dalam Islam; terjemahan oleh H.M. Rasjidi. Jakarta: N.V. Bulan Bintang.

Fantani, Amintore. 1935. Catholicism, Protestant and Capitalism. London: Sheed and Ward Ltd.

Khaldun, Ibn. 2000. Muqaddimah; terjemahan Ahmadie Thoha. Jakarta: Pustaka Firdaus.

Kuntowijoyo. 2006. Budaya dan Masyarakat. Yogyakarta: Tiara Wacana.

. 1997. Identitas Politik Umat Islam. Bandung: Mizan.

Lapian. 2009. Orang Laut, Bajak Laut: Sejarah Kawasan Laut Sulawesi Abad XIX. Jakarta: Komunitas Bambu.

Miles, Matthew B. dan A. Michael Huberman. 1992. Qualitative Data Analysis; terjemahan Tjejep Rohendi Rohidi. Jakarta: UI Press. 
Musa, Muhammad Yusuf. Islam: Suatu Kajian Komprehensif; terjemahan oleh A. Malik Madaniy dan Hamim. Jakarta: Rajawali.

Nash, Laura. Ethic Without the Sernon dalam Petter Marsden dan Jang Shafrits (ed.), Essential Business Ethics. New York: Penguin.

Natsir, Nanat Fatah. 1999. Etos kerja Wirausahawan Muslim. Bandung: Gunung Djati Press.

Pelras, Christian. 2006. The Bugis; Abdul Rahman Abu, dkk. Jakarta: Nalar.

Qodir, Zuly. 2002. Agama \& Etos Dagang. Solo: Pondok Edukasi.

Rahardjo, Dawam. 1999. Islam dan Transformasi Sosial Ekonomi. Jakarta: LSAF.

Rahim, Rahman. 2011. Nilai-Nilai Utama Kebudayaan Bugis. Yogyakarta: Ombak.

Tasmara, Toto. 1995. Etos Kerja Pribadi Muslim. Yogyakarta: Dana Bhakti Wakaf.

Taufik, Abdullah (Ed.). 1982. Agama, Etos Kerja dan Perkembangan Ekonomi. Jakarta: LP3ES.

Tobroni dan Syamsul Arifin. 1994. Islam Pluralisme Budaya dan Politik: Refleksi Theologi Untuk Aksi dalam Keberagaman dan Pendidikan. Yogyakarta: SIPRESS.

Turner, Bryan S. 1984. Sosiologi Islam: Suatu Telaah Analitis atas Tesa Sosiologi Weber; terjemahan GA Tocialu. Jakarta: Rajawali Press.

Tawney, RH. 1964. Religion and the of Capitalism. London: John Murray. 
20 Millah Vol. XIV, No. 1, Agustus 2014 